\title{
Plant litter composition and stable isotope signatures vary during decomposition in blue carbon ecosystems
}

\author{
J. J. Kelleway $\mathbb{D} \cdot$ S. M. Trevathan-Tackett $\mathbb{D}$ • \\ J. Baldock 1 - L. P. Critchley $(\mathbb{D}$
}

Received: 29 September 2021 / Accepted: 11 January 2022 / Published online: 1 February 2022

(C) The Author(s) 2022

\begin{abstract}
The ratio of isotopes of carbon $\left({ }^{13} \mathrm{C}:{ }^{12} \mathrm{C}\right.$ or $\left.\delta^{13} \mathrm{C}\right)$ and nitrogen $\left({ }^{15} \mathrm{~N}:{ }^{14} \mathrm{~N}\right.$ or $\left.\delta^{15} \mathrm{~N}\right)$ are common indicators of the flow and storage of organic matter in coastal wetland research. Effective use of these indicators requires quantification and understanding of: (1) the variability of isotope signatures of potential organic matter source materials; and (2) the influence of organic matter decomposition on isotopic signatures. While it is well-established that organic matter characteristics change during the decomposition
\end{abstract}

Responsible Editor: Christian Lønborg.

Supplementary Information The online version contains supplementary material available at https://doi. org/10.1007/s10533-022-00890-3.

\section{J. J. Kelleway $(\square)$}

School of Earth, Atmospheric and Life Science,

GeoQuEST Research Centre, University of Wollongong,

Wollongong, NSW, Australia

e-mail: jeffreyk@uow.edu.au

S. M. Trevathan-Tackett

Centre for Integrative Ecology, School of Life and Environmental Sciences, Deakin University, Burwood, VIC, Australia

J. Baldock

CSIRO Agriculture and Food, Glen Osmond, SA,

Australia

L. P. Critchley

Department of Biological Sciences, Macquarie University,

Sydney, NSW, Australia process, there has been little direct quantification of any concurrent shifts in isotope signatures for coastal detritus. In this study, we addressed this by quantifying: (1) shifts in sample composition using solidstate ${ }^{13} \mathrm{C}$ Nuclear Magnetic Resonance (NMR) spectroscopy; and (2) shifts in $\delta^{13} \mathrm{C}$ and $\delta^{15} \mathrm{~N}$ signatures of coastal plant tissues from field litterbag experiments. We observed significant shifts in ${ }^{13} \mathrm{C}$ NMR spectra across the course of deployment for all four plant tissues assessed (leaves of mangrove Avicennia marina; branchlets of supratidal tree Casuarina glauca; leaf wrack and roots/rhizomes of the seagrass Zostera muelleri), driven largely by the preferential loss of labile constituents and concentration of more resistant macromolecules, such as lignin and leaf waxes. While there were shifts in isotope ratios for all species, these varied in direction and magnitude among species, tissue type and isotopes. This included $\delta^{13} \mathrm{C}$ enrichments of up to $3.1 \%$ and $2.4 \%$ o in leaves of A. marina, and branchlets of C. glauca, respectively, but $\delta^{13} \mathrm{C}$ depletions of up to $4.0 \%$ for Z. muelleri. Shifts in $\delta^{15} \mathrm{~N}$ varied among species and tissue types, with few clear temporal patterns. Partial least squares regression analyses showed that some tissue isotope signatures can be reliably predicted on the basis of sample composition $\left({ }^{13} \mathrm{C}\right.$ NMR spectra), however, multiple inter- and intra-species variations preclude a simple explanation of isotopic signature shifts on the basis of plant-material molecular shifts alone. Further, we cannot preclude the potential influence of microbe-associated organic matter on sample 
composition or isotopic signatures. Our findings emphasise the importance of considering decomposition effects on stable isotope signatures in blue carbon ecosystems. Isotope approaches will remain a valuable tool in coastal ecosystem research, but require robust experimental approaches (including appropriate use of decomposed end-members or fractionation correction factors; quantification of microbial organic matter) and quantification of decomposition dynamics for specific plant tissues and environmental settings.

Keywords Mangrove - Seagrass - Coastal wetland · Blue carbon · Decay $\cdot$ Organic matter

\section{Introduction}

Vegetated coastal ecosystems, including seagrass meadows, saltmarshes, mangroves and other tidal forests, are recognised among the most productive ecosystems on earth (Duarte et al. 2013; Krauss et al. 2018; Serrano et al. 2019). This high productivity supports multiple ecosystem services, including: provision of energy and nutrients underpinning coastal and offshore biodiversity and fisheries production (Nagelkerken et al. 2008; Odum \& Heald 1975); moderation of biochemical processes, including ocean acidity (Sippo et al. 2016; Wang et al. 2016); and carbon sequestration over centennial to millennial time-scales (i.e. blue carbon) (McLeod et al. 2011; Rogers et al. 2019a). Measuring the flow and/or storage of organic matter (OM) is therefore of importance to our understanding of biochemical connectivity among terrestrial, coastal and marine ecosystems (Abrantes et al. 2015; Alongi et al. 1989; Guest \& Connolly 2004; Hemminga et al. 1994). It is also becoming increasingly important in the valuation and accounting of ecosystem services, including the implementation and monitoring of carbon trading and offset projects under blue carbon accounting frameworks (Needelman et al. 2018).

The flow of OM via degradation processes is an important component of carbon cycling budgets (and associated modelling approaches) in blue carbon ecosystems (Arndt et al. 2013; Cebrián et al. 1997; Ouyang et al. 2017). These processes include the decomposition of freshly deposited OM from plants and other autotrophs (e.g. benthic algae)typically over timescales of hours to months-and the (re)mineralisation of bulk soil or sediment OM, which may extend to centuries or millennia (Goulter \& Allaway 1979; Kelleway et al. 2017b; Rogers et al. 2019a). The outcome of these degradation processes can include incorporation of OM into foodwebs, and/ or the outward flux of greenhouse gasses through various aerobic and anaerobic pathways and transportation processes (Alongi 2014; Duarte \& Cebrian 1996; Maher et al. 2018; Mazumder et al. 2011). The OM that escapes breakdown and transportation has the potential to be sequestered in the substrate and represents an important blue carbon pool (Hyndes et al. 2013; Jennerjahn 2020).

Controls on OM decomposition are diverse and include rate of OM input, temperature, oxygen exposure and the enzymatic capacity of the resident microbial communities (Arndt et al. 2013; Burdige 2007; Cragg et al. 2020). The chemical composition of the plant detritus, in part, influences the breakdown of OM by microbial decomposers (Spivak et al. 2019). For example, the preferential removal of more labile components (e.g. amino acids, polysaccharides) during decomposition leads to the relative enrichment of more recalcitrant OM (e.g. lignin, lipids/waxes) (Benner et al. 1987; Trevathan-Tackett et al. 2017). In addition, a variety of OM sources may accumulate within blue carbon ecosystems, including autochthonous (in-situ production) and allochthonous (external OM) materials of varying recalcitrance (Kelleway et al. 2017a; Kennedy et al. 2004; Trevathan-Tackett et al. 2015, 2017). This complexity emphasises the need for robust biochemical indicators to estimate the source and preservation of various types of $\mathrm{OM}$ in blue carbon ecosystems.

The ratio of stable isotopes of carbon $\left({ }^{13} \mathrm{C}:{ }^{12} \mathrm{C}\right.$ or $\left.\delta^{13} \mathrm{C}\right)$ and nitrogen $\left({ }^{15} \mathrm{~N}:{ }^{14} \mathrm{~N}\right.$ or $\left.\delta^{15} \mathrm{~N}\right)$ are two of the most commonly used indicators of organic matter provenance, transport and cycling in coastal ecosystems. This includes widespread application in food web studies (e.g. Abrantes et al. 2015; Bouillon et al. 2011; Lee 2000; Loneragan et al. 1997; Mazumder et al. 2019) and increasing application (of $\delta^{13} \mathrm{C}$ particularly) in coastal wetland sedimentary reconstructions (e.g. Johnson et al. 2007; Kelleway et al. 2017a; Rogers et al. 2019b) and blue carbon flux studies (Geraldi et al. 2019; Kennedy et al. 2010; Maher et al. 2013, 2017).

The utility of this approach lies in the fact that different OM sources can have distinct $\delta^{13} \mathrm{C}$ and/or $\delta^{15} \mathrm{~N}$ 
values. Variation in $\delta^{13} \mathrm{C}$ among broad primary producer groupings (e.g. C3 vs $\mathrm{C} 4$ photosynthetic pathways; aquatic vs atmospheric $\mathrm{C}$ fixers; algae vs higher plants) has led to use of $\delta^{13} \mathrm{C}$ as a primary indicator of OM source (Beer 1989; France 1995; Mazumder et al. 2011; Smith \& Epstein 1971). Variation in $\delta^{15} \mathrm{~N}$ has been used in many instances as a complement to $\delta^{13} \mathrm{C}$ for source determination, but is also used, independently, as an indicator of eutrophication (Cole et al. 2004). Predictable isotopic enrichment as prey $\mathrm{OM}$ is assimilated by a predator forms the basis for use of $\delta^{15} \mathrm{~N}$ (enrichment of $\sim 3.4 \%$ commonly used) and $\delta^{13} \mathrm{C}$ (enrichment of $<1 \%$ ) as trophic-level indicators (Boecklen et al. 2011; Post 2002).

Reliable apportioning of OM sources and flux using $\delta^{13} \mathrm{C}$ and/or $\delta^{15} \mathrm{~N}$ values requires: (A) knowledge of potential source values and their variability; (B) sources with sufficiently distinct values; and (C) accounting of any alteration (fractionation) of source values during decomposition (Geraldi et al. 2019; Kelleway et al. 2018). While there continue to be advances regarding (A) (Cernusak et al. 2013; Diefendorf et al. 2010; Farquhar \& Richards 1984; Kelleway et al. 2018), and (B) is subject to consideration of specific settings and experimental design; (C) remains an understudied topic for many coastal settings.

Examination of detrital isotope signatures in coastal wetlands has focused largely on the fate of leaf litter of mangroves and seagrass (Dehairs et al. 2000; Dittmar et al. 2006; Kristensen et al. 2008; Rodelli et al. 1984). Isotopic fractionation of seagrass, saltmarsh and mangrove leaves during decomposition has been reported in some studies as low or negligible (i.e. $<1 \%$ over $28-168$ days of decay,Lanari et al. 2018; Yang et al. 2018; Zieman et al. 1984)). However, larger variations ( $>2 \%$ ) can occur, including for $\delta^{15} \mathrm{~N}$ and/or longer-term studies of $\delta^{13} \mathrm{C}$ (Benner et al. 1991; Fourqurean \& Schrlau 2003; Marquez et al. 2017). These varied outcomes highlight our need to better understanding the relationships between plant decomposition dynamics and isotope signatures over a range of coastal settings and timeframes, and the implications for providence and trophic model interpretations.

There are two main methods by which the relationships between plant molecular shifts and isotope signatures have been investigated. The analysis of targeted compounds-chemically extracted from a sample- has been used in 'compound-specific stable isotope analyses' from fresh plant and/or detrital sources (e.g. Benner et al. 1987; Dai 2005; Tanner et al. 2010). An alternative approach has been the measurement of identical bulk samples using both isotope ratio and composition analysis methods (e.g. Benner et al. 1990; Dickens et al. 2006; Golchin et al. 1995). In this study, we take the latter approach, characterising compositional shifts via ${ }^{13} \mathrm{C}$ Nuclear Magnetic Resonance $\left({ }^{13} \mathrm{C}\right.$ NMR) from field litterbag deployments of four different coastal plant tissues. We then quantify the bulk stable isotope ratios $\left(\delta^{13} \mathrm{C}\right.$ and $\delta^{15} \mathrm{~N}$ ) of the same samples in order to determine the nature of any relationships between sample OM composition and isotopic indicators (Fig. 1). We test the following hypotheses: (1) there would be significant shifts in OM composition over time for each of the plant tissues tested; (2) there would be significant shifts in isotope values over time among the plant tissues tested; (3) any shifts in isotope ratios could be explained by concurrent shifts in OM composition.

\section{Methods}

Litter deployment and collection

Litter bags provide a standardised method with which to assess in situ OM decomposition (Cummins et al. 1980). In this study, we utilised samples previously subjected to controlled litter deployment and decomposition assessment in the Sydney region, Australia. The species and tissues targeted were leaves of the cosmopolitan mangrove Avicennia marina; photosynthetic branchlets of the supratidal tree Casuarina glauca (leaves are highly reduced in this genus); and both belowground (root/rhizome) and aboveground (leaf wrack) tissues of the seagrass Zostera muelleri.

A. marina and C. glauca are trees which utilise the $\mathrm{C} 3$ photosynthetic pathway, with measurements of live biomass $\delta^{13} \mathrm{C}$ typically in the range -25 to -31 $\% o$ (Ball 1988). As with many other seagrass taxa, there remains uncertainty as to the use of $\mathrm{C} 3 \mathrm{and} / \mathrm{or}$ C4 pathways by Z. muelleri (Kim et al. 2018), with live leaf $\delta^{13} \mathrm{C}$ measurements in the range -4 to -20 $\% o$ (Kennedy et al. 2010), potentially explained by its photosynthetic pathway or by the fixation of dissolved $\mathrm{CO}_{2}$ in the water column, rather than atmospheric $\mathrm{CO}_{2}$. C. glauca has a high nitrogen fixation 


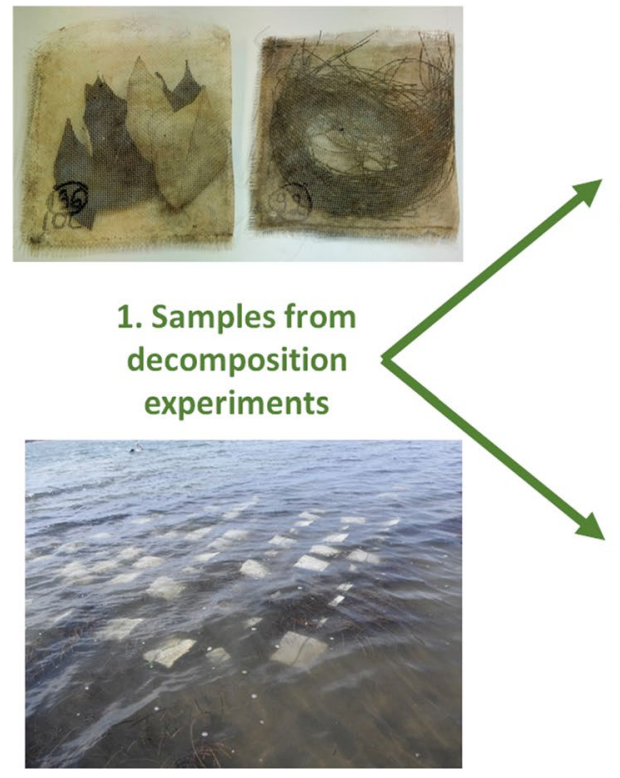

Fig. 1 Analytical framework for this study

\section{Carbon composition \\ analysis \\ ( ${ }^{13}$ C NMR)}

Characterise compositional shifts during decomposition

\section{Stable isotope analysis}

$\left(\delta^{13} \mathrm{C} ; \delta^{15} \mathrm{~N}\right)$

Quantify shifts in isotope

signatures during

decomposition capacity through its root nodule symbiosis with the nitrogen fixing actinobacteria Frankia (Diouf et al. 1995), which may explain the near zero $\delta^{15} \mathrm{~N}$ values consistently seen in $C$. glauca plant tissue in its native range (Kurdali \& Al-Shamma'A 2009; J. Kelleway, unpublished data). In contrast, it has been shown that $\delta^{15} \mathrm{~N}$ signatures of plants located lower in the tidal frame are influenced by water column inorganic nitrogen loads (Cole et al. 2004).

The full details of litterbag preparation, deployment, collection and temporal decomposition trends are presented in Critchley et al. (2021) for A. marina and C. glauca, and in Trevathan-Tackett et al. (2020) for Z. muelleri. Briefly, for A. marina and $C$. glauca, mature leaves that appeared most likely to become detached during storm events were collected from trees in Majors Bay Reserve, Yaralla Bay within Sydney Harbour, New South Wales, Australia $\left(-33.844^{\circ} \mathrm{S}, 151.099^{\circ} \mathrm{E}\right)$. Leaves were rinsed, patted of excess moisture, and weighed into $\sim 10 \mathrm{~g}$ quantities, with wet weights recorded to the nearest $1 \mathrm{mg}$, then placed in $100 \times 150 \mathrm{~mm}$ bags made of $1 \mathrm{~mm}$ nylon mesh: this mesh size resembles that of loose, naturally entrained leaves in deposition zones (Cummins et al. 1980). These litterbags were deployed on the wetland surface within the intertidal zone. Three replicate litter bags were selected for analysis at each of the following durations after deployment: 7, 21, 42, and 77 days.

For Z. meulleri, fresh, green leaf wrack was collected along the shoreline of Fagans Bay, New South Wales, Australia $\left(33.431^{\circ} \mathrm{S}, 151.321^{\circ} \mathrm{E}\right)$. In contrast, root/rhizome material was collected in situ, from living plants. Tissues were washed of sediment and infauna before storage at $-20{ }^{\circ} \mathrm{C}$ to stop decay processes before the start of the experiment. The biomass was brought to room temperature, patted of excess moisture and packed into $300 \times 300 \mathrm{~mm}$ (leaf, $500 \mathrm{~g}$ ) or $150 \times 150 \mathrm{~mm}$ (rhizome/root, $60 \mathrm{~g}$ ) litter bags (1.0 mm polyester mesh; Miami Aqua-culture, Inc.,Miami, FL,USA). The seagrass leaf litterbags were deployed at the sediment surface, while the root/ rhizome litterbags were buried within the rhizosphere. For both seagrass experiments, three replicate litter bags were selected for analysis at each of the following durations after deployment: 14, 168, 389, and 729 days.

For all species/tissue types, three replicates of initial sample material were washed and dried at $60{ }^{\circ} \mathrm{C}$ without being deployed to represent $t_{0}$ samples. Upon collection, the litter in the mesh bags was washed of sediments, infauna or algal growth, dried at $60{ }^{\circ} \mathrm{C}$, then kept in cool, dry storage until chemical analyses in the present study (Fig. 1). While care was taken 
to remove non-plant materials, the incorporation of microbial-associated organic matter (including autotrophic fixation) cannot be discounted. All samples were homogenised and ground to a fine powder (Pulvisette 7, Fritsch, Germany) prior to chemical analyses.

\section{${ }^{13} \mathrm{C}$ NMR}

Solid-state ${ }^{13} \mathrm{C}$ NMR (nuclear magnetic resonance) spectroscopy was used to characterise the molecular composition of carbon within each plant litter sample (Baldock et al. 2004). Cross-polarization ${ }^{13} \mathrm{C}$ NMR spectra were acquired using a 200 Avance spectrometer (Bruker Corporation, Billerica, MA, USA) following the instrument specifications, experimental procedures, and spectral processing outlined by Baldock et al. (2013b). Spectra were normalised to a constant total signal intensity, truncated to the $0-200 \mathrm{ppm}$ range, within which the dominant forms of carbon include alkyl C (dominant in 0-45 ppm), N-alkyl/ methoxyl C (45-60 ppm), O-alkyl C (60-95 ppm), Di-O-alkyl C (95-110 ppm), aryl C (110-145 ppm), O-aryl C (145-165 ppm), amide/carboxyl C (165-190 ppm), and ketone C (190-200 ppm) (Baldock \& Smernik 2002).

Stable isotope analyses

$\delta^{13} \mathrm{C}$ and $\delta^{15} \mathrm{~N}$ were estimated for all samples using an isotope ratio mass spectrometry-elemental analyzer (Thermo DeltaV) at University of Hawaii (HILO). Two quality control reference samples were also included in each analytical run, while a twopoint calibration was used to normalise the data using standards USGS40 and USGS41. Results are accurate to $0.2 \%$ of measured $\delta^{13} \mathrm{C}$ values (reported relative to Vienna Pee Dee Belemnite) and $0.2 \%$ of measured $\delta^{15} \mathrm{~N}$ values (reported relative to air).

\section{Data analysis}

Multifactorial permutational analyses of variance (PERMANOVAs) were used to investigate differences among ${ }^{13} \mathrm{C}$ NMR spectra across the course of the decomposition experiments. Separate PERMANOVAs were completed for each tissue type, while pairwise comparisons were used to identify differences among time points. Monte Carlo-approximated $\mathrm{P}$ values $(\mathrm{P}(\mathrm{MC})$ ) were used to interpret comparisons with low numbers of unique permutations (i.e. $<10$ ). These analyses were based on Euclidean distance resemblance matrices and were performed using PRIMER version 6 with PERMANOVA add-on (PRIMER-E, Auckland, New Zealand).

Principal components analysis (PCA) was performed using the normalised ${ }^{13} \mathrm{C}$ NMR spectra to: (1) identify temporal trends in composition among samples over the course of the decomposition experiments; and (2) define the ${ }^{13} \mathrm{C}$ NMR spectral components most important to differentiating the samples. Loadings were plotted for the first two principal components to assist in the latter and to guide interpretation of differences in composition among samples.

Variations in stable isotope values $\left(\delta^{13} \mathrm{C}\right.$ and $\delta^{15} \mathrm{~N}$ ) were assessed in several ways, with separate analyses conducted in all instances for each of the four tissue types and two isotopes analysed. First, isotope values were regressed against deployment time, with linear or exponential decay relationships fitted as appropriate. Second, one-way analyses of variance (ANOVAs) were performed to test for significant variations in isotope values between all of the sampling periods, including original materials $\left(\mathrm{t}_{0}\right)$. Welch's $F$-tests were used where the homogeneity of variance assumption was not met (Delacre et al. 2019), while Bonferonni (ANOVAs) and Games-Howell (Welch tests) post-hoc comparisons were also undertaken.

Partial least-squares regression analysis (PLSR) has been widely used to predict soil and plant carbon concentrations and/or carbon fractions on the basis of spectroscopic data (Baldock et al. 2013a; Hayes et al. 2017; Wold et al. 2001). In this study, we used PLSR to test whether sample stable isotope ratios $\left(\delta^{13} \mathrm{C}\right.$ and $\left.\delta^{15} \mathrm{~N}\right)$ could be predicted from ${ }^{13} \mathrm{C}$ NMR spectra. PLSR is useful in this instance as it extracts a set of orthogonal factors from potentially numerous and highly-correlated predictor variables (i.e. NMR spectra) and response variables (i.e. stable isotope signatures). Separate analyses were conducted for each tissue type and each isotope ratio, whereby all samples across the time series were used to calibrate models, and also to validate models using a leave-one-out cross-validation approach. 


\section{Results}

\section{OM composition}

For Avicennia marina leaf samples, there were significant shifts in spectral signatures over the course of the litter deployment period $(\mathrm{P}(\mathrm{MC})=0.001$; Table S1). There were increases in spectral intensity in the region $20-40 \mathrm{ppm}$, and at $150-155 \mathrm{ppm}$, with decreases at 72-76 ppm, 113-120 ppm and 142-150 ppm, and an initial decrease only at 56 ppm (methoxy C) (Fig. 2a). There were significant pairwise differences between $t_{0}$ and $t_{7}$ spectra, as well as these two sampling events versus the three later events (pairwise comparison $\mathrm{P}(\mathrm{MC})$ values $<0.05$ ), consistent with their distribution along PC1 (Table S1; Figure S1). There were no significant differences among $\mathrm{t}_{21}, \mathrm{t}_{42}$ and $\mathrm{t}_{77}$ despite some separation along PC2 (Table S1; Figure S1).
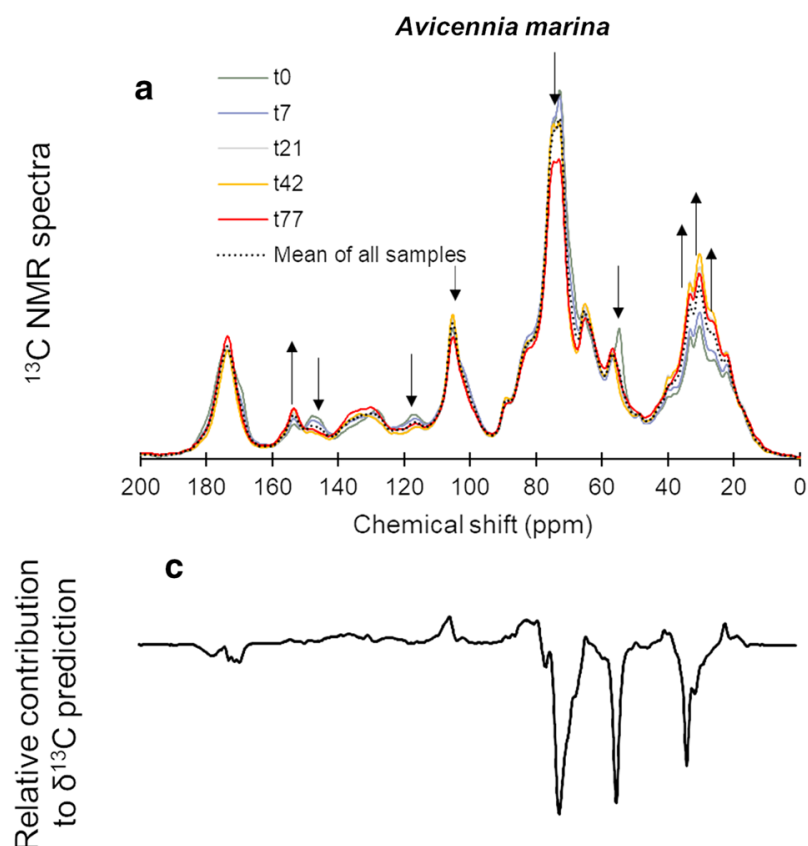

Fig. 2 Mean ${ }^{13} \mathrm{C}$ NMR spectra of decomposition samples for Avicennia marina (a) and Casuarina glauca (b) colour coded by collection time (replicate $n=3$ ). Arrows represent the direction of shifts in spectra across the course of the experimental period (blue and red arrows represent shifts in a similar or opposite direction, respectively, to that observed for $A$. marina). Lower plots (c, d) display the mean relative contribution of variation in ${ }^{13} \mathrm{C}$ NMR spectra toward the prediction
For Casuarina glauca branchlets, shifts in ${ }^{13} \mathrm{C}$ NMR spectra over the course of deployment included increases in spectral intensity at 142-147 ppm and 150-155 ppm (both in common with A. marina), but opposing trends to A. marina of decreasing intensity at $56 \mathrm{ppm}$ (methoxy C) and in the range 20-40 ppm (Fig. 2b). There was a significant difference between $\mathrm{t}_{0}$ and all sampling events after $\mathrm{t}_{7}$ (pairwise comparison $\mathrm{P}(\mathrm{MC})$ values $<0.05$ ), with $\mathrm{t}_{0}$ through $\mathrm{t}_{21}$ separated across $\mathrm{PC} 2$, followed by later separation across PC1 $\left(\mathrm{t}_{42}, \mathrm{t}_{77}\right.$; Table S1; Figure S1b).

For Zostera muelleri leaf wrack, significant differences among time periods $(\mathrm{P}(\mathrm{MC})=0.0016)$ were driven by longer-term shifts in ${ }^{13} \mathrm{C}$ NMR spectra (Fig. 3a). That is, pairwise comparisons showed differences were only significantly different at $\mathrm{P}(\mathrm{MC})<0.05$ from $\mathrm{t}_{0}$ by the final sampling period $\left(\mathrm{t}_{729}\right)$, though all other comparisons to $\mathrm{t}_{0}$ had $\mathrm{P}(\mathrm{MC})$ values $<0.1$ (Table $\mathrm{S} 1$ ) and some separation among the first two principle components (Figure S2a).

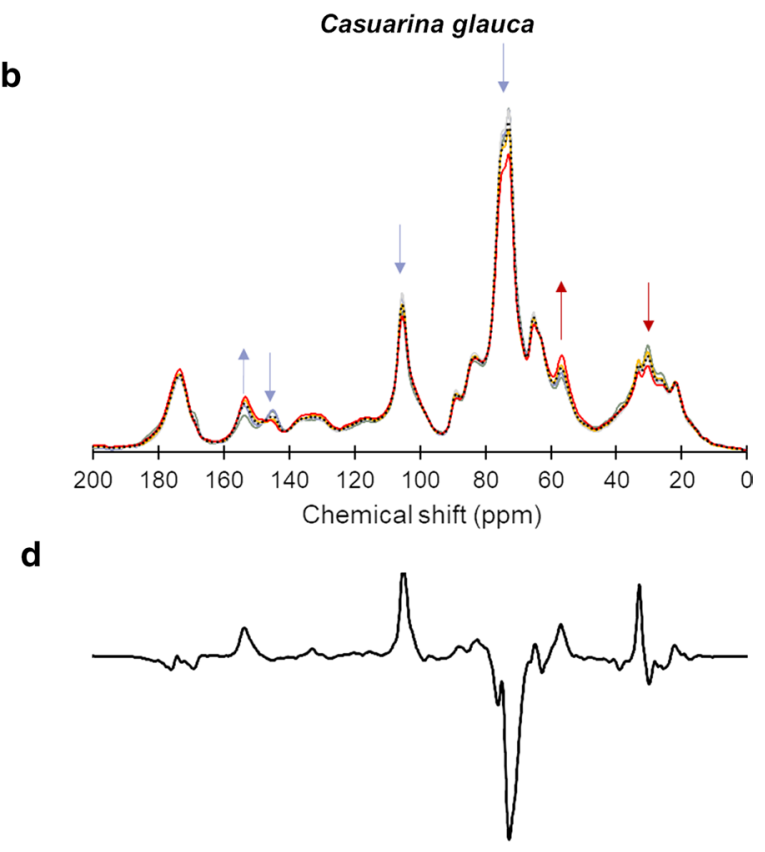

of $\delta^{13} \mathrm{C}$ as determined through partial least squares regression. This contribution was calculated by multiplying the PLS regression $\beta$-coefficient (averaged across all samples for a species) by the spectral intensity (averaged across all samples for a species) for each unit of chemical shift (ppm). The size of peaks and troughs in $\mathbf{c}$ and $\mathbf{d}$ therefore signify relative importance to the predictive models 
Zostera muelleri leaf wrack

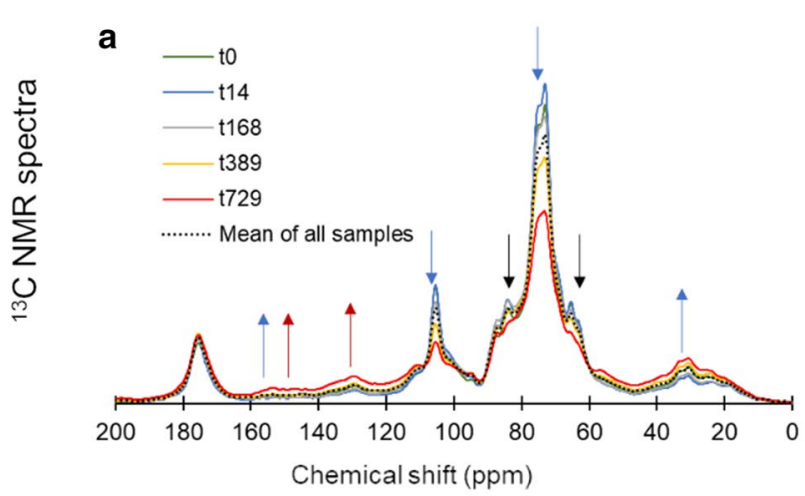

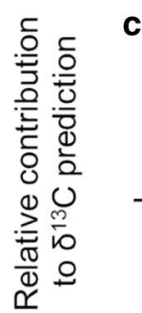

Fig. 3. ${ }^{13} \mathrm{C}$ NMR spectra of decomposition samples for Zostera muelleri leaf wrack (a) and root/rhizome (b) colour coded by collection time (replicate $n=3$ ). Arrows represent the direction of shifts in spectra across the course of the experimental period (red arrows represent shifts in an opposite direction to that observed for A. marina). Lower plots (c, d) display the mean relative contribution of variation in ${ }^{13} \mathrm{C}$ NMR spectra

Similarly, for Z. muelleri root/rhizome, significant overall difference was also driven by longer term shifts in ${ }^{13} \mathrm{C}$ NMR spectra-in this case significant differences only between $t_{14}$ and $t_{729}$ and between $\mathrm{t}_{168}$ and $\mathrm{t}_{729}$ (Table $\mathrm{S} 1$ ).

Inspection of ${ }^{13} \mathrm{C}$ NMR spectra revealed increases over time for both seagrass tissue types in intensity in the range 20-40 ppm, and decreases over time at 72-76 ppm (Fig. 3a,b) - both in common with $A$. marina. In contrast to $A$. marina, there were broad increases in the range 115-160 ppm (including peaks at 128 and $150 \mathrm{ppm}$ ) for late-stage samples. There were broad similarities in magnitude and direction of spectral shifts for leaf wrack and root/ rhizome over the experimental period (Fig. 3a, b), with the first principal component capturing similar variability (Figure S2a, b), with broadly similarthough inverse-coefficient plots (Figure S2c, d).
Zostera muelleri root/rhizome

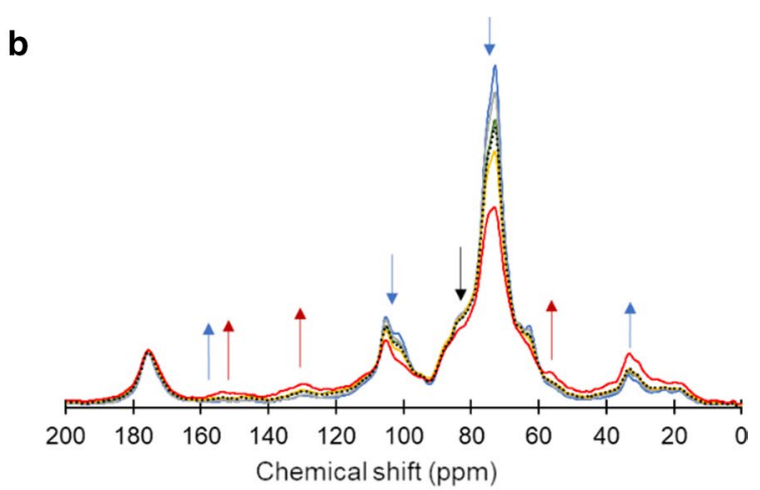

d

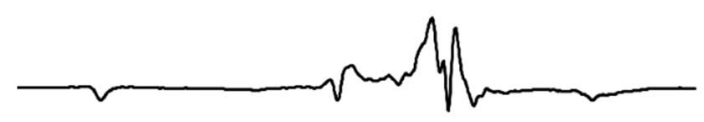

toward the prediction of $\delta^{13} \mathrm{C}$ as determined through partial least squares regression. This contribution was calculated by multiplying the PLS regression $\beta$-coefficient (averaged across all samples for a species) by the spectral intensity (averaged across all samples for a species) for each unit of chemical shift (ppm). The size of peaks and troughs in $\mathbf{c}$ and $\mathbf{d}$ therefore signify relative importance to the predictive models

\section{Isotopic signatures}

For A. marina and C. glauca, $\delta^{13} \mathrm{C}$ signatures experienced shifts best described by exponential decay models (Fig. 4a, b). That is, there was a significant enrichment in A. marina leaf $\delta^{13} \mathrm{C}$ between deployment $\left(\mathrm{t}_{0}\right)$ and the first collection $\left(\mathrm{t}_{7}\right)$ (mean shift $=2.8 \%$; $\mathrm{P}<0.01$ ), but little change through the remainder of the experimental period (Fig. 4a; Fig. S3a). Similarly, a significant, though smaller initial shift was also observed for branchlets of the $C$. glauca (mean shift $=1.6 \%$; $\mathrm{P}<0.001$ ), as part of an exponential decay (Adj. $\mathrm{R}^{2}=0.89$; Fig. 4b; Fig. S3d). In contrast, fractionation of $Z$. muelleri occurred in the opposite direction (i.e. a depletion in $\delta^{13} \mathrm{C}$ ), exhibiting a strong relationship for root/rhizome (Adj. $\mathrm{R}^{2}=0.89 ; \mathrm{P}<0.001$; Fig. 4d; Table S2; Figure S4d), and a weak linear relationship for leaf wrack (Adj. 

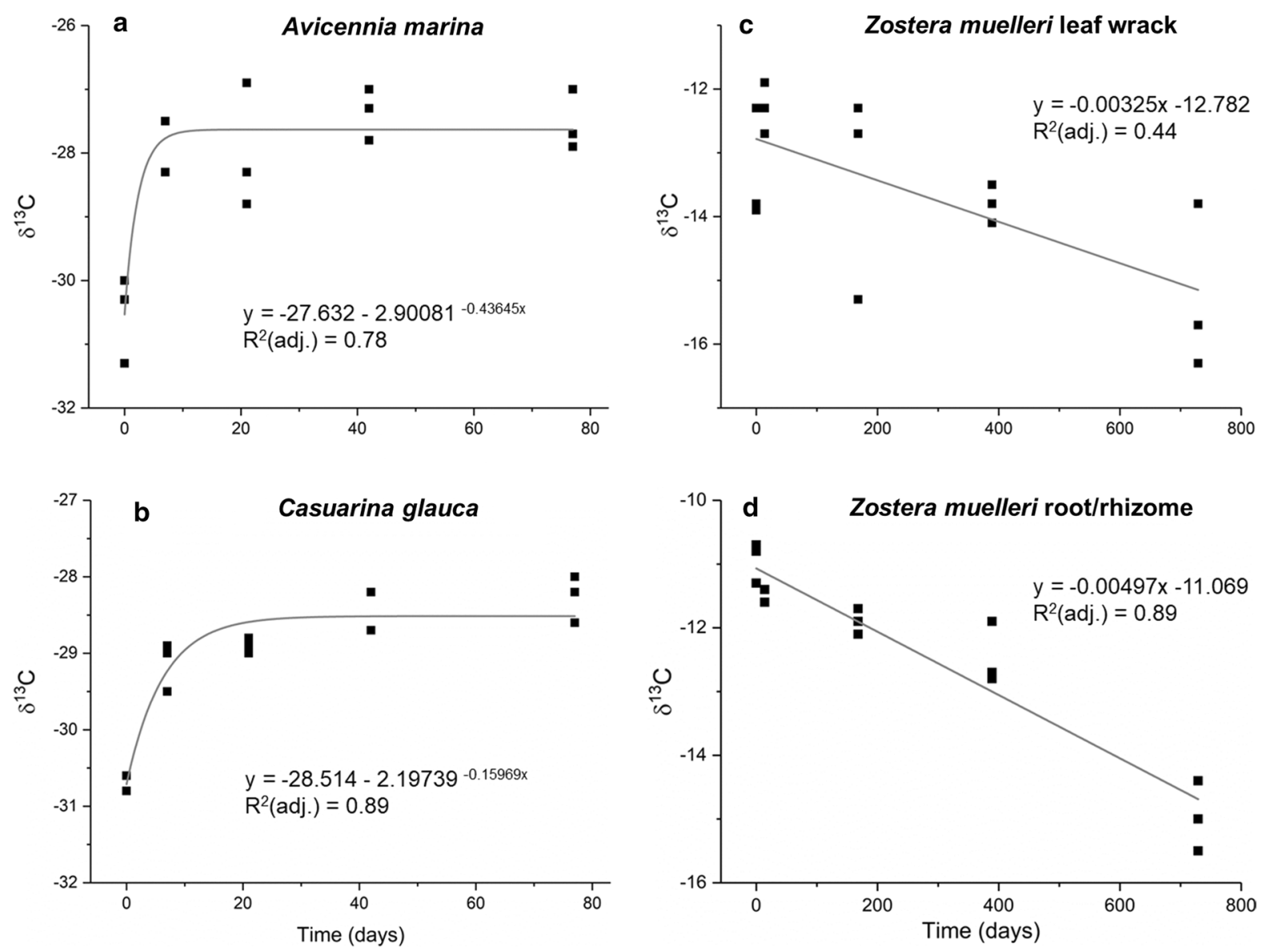

Fig. 4 Scatterplots and selected regression models of $\delta^{13} \mathrm{C}$ variation as a function of time (days) of litterbag deployment for Avicennia marina leaf (a), Casuarina glauca branchlet (b), and Zostera muelleri leaf wrack (c) and root/rhizome (d)

$\mathrm{R}^{2}=0.44$; Welch $\mathrm{P}=0.044$; Fig. 4c; Table S3; Figure $\mathrm{S} 4 \mathrm{a})$.

For $\delta^{15} \mathrm{~N}$, there were significant overall differences among sampling periods for all sample types, except Z. muelleri root/rhizome (Tables S2, S3). Pairwise comparisons of sampling periods showed initial $\left(\mathrm{t}_{0}\right.$ to $\mathrm{t}_{7}$ ) shifts of a similar magnitude observed in $\delta^{15} \mathrm{~N}$ between A. marina (mean shift $=2.2 \%$; $\mathrm{P}=0.015$ ) and $C$. glauca (mean shift $=-2.0 \%$; $\mathrm{P}=0.003$ ), however these were in opposite directions to one another (Fig. 5). After $t_{7}$ there were no clear trends for either species, with values moderating between the $t_{0}$ and $\mathrm{t}_{7}$ values. There was a significant depletion in $\delta^{15} \mathrm{~N}$ for Z. muelleri leaf wrack $(\mathrm{P}<0.001)$. While this returned a moderate linear fit $\left(\right.$ Adj. $\left.R^{2}=0.60\right)$, separation between fresh and short-term deployment and longer-term deployment suggests non-linear trends (Fig. 5c).

Predicting isotope ratios

The analytical measurements of $\delta^{13} \mathrm{C}$ and $\delta^{15} \mathrm{~N}$ ratios were compared against predictions of these ratios based upon their ${ }^{13} \mathrm{C}$ NMR spectrum (Fig. 6). Prediction capacity was greatest for $\delta^{13} \mathrm{C}$ of $C$. glauca branchlets (validation $\mathrm{R}^{2}=0.91$ ) with a prediction RMSE of $0.29 \%$, followed by $\delta^{13} \mathrm{C}$ of $A$. marina leaves $\left(\mathrm{R}^{2}=0.74\right)$. Prediction capacity was lower, though moderate, for $Z$. muelleri $\delta^{13} \mathrm{C}$. Although calibration data returned moderate to high $\mathrm{R}^{2}$ values for all $\delta^{15} \mathrm{~N}$ tests, weaker relationships for validation values suggest a low predictive capacity, except for $Z$. 

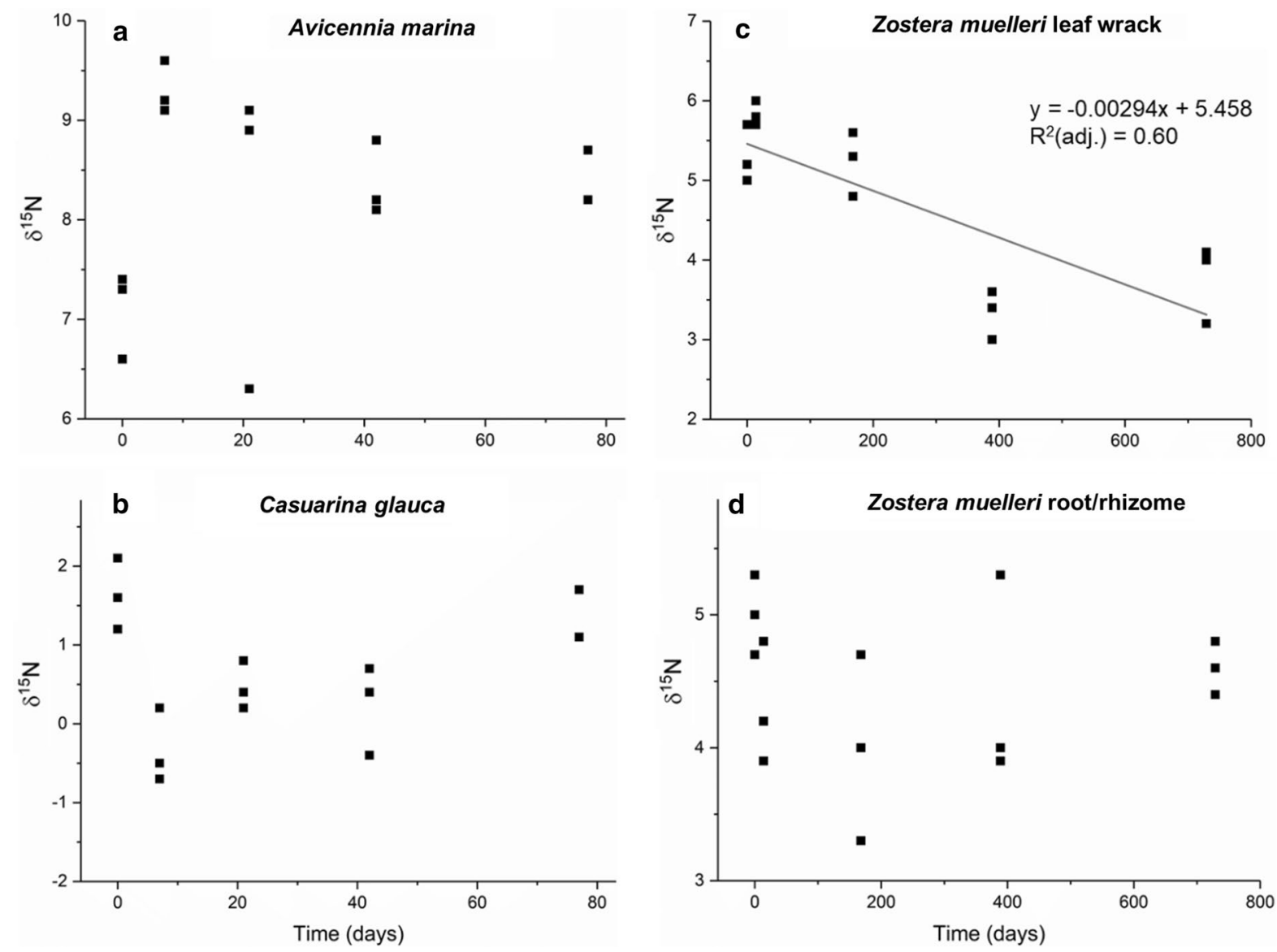

Fig. 5 Scatterplots and selected regression model of $\delta^{15} \mathrm{~N}$ variation as a function of time (days) of litterbag deployment for Avicennia marina leaf (a), Casuarina glauca branchlet (b), and Zostera muelleri leaf wrack (c) and roots/rhizomes (d)

muelleri leaf wrack where predictive capacity appears moderate $\left(\mathrm{R}^{2}=0.69\right.$; prediction $\mathrm{RMSE}=0.6 \%$ ) .

Inspection of the $\delta^{13} \mathrm{C}$ PLSR $\beta$-coefficient plots reveals several differences among taxa. While there were significant peaks or troughs across the range 65-85 ppm for all taxa, the direction and specific position of these varied among the tree versus seagrass samples. That is, there were broad troughs (negative coefficients) for $A$. marina (Fig. 2c) and $C$. glauca (Fig. 2d) in this range, but a series of peaks (positive coefficients) at 69-70 and 74-82 ppm and troughs at 65 and $72 \mathrm{ppm}$ for the two seagrass tissues (Fig. 3c, d). The tree tissues also had peaks centred at 105 ppm (larger for C. glauca relative to A. marina), whereas the seagrass tissues had narrow troughs here. Outside these spectral ranges, A. marina alone exhibited broad troughs at 52-56 ppm and 25-35 ppm, the latter of which was contrasted by a peak for $C$. glauca
(31-35 ppm). The relative $\beta$-coefficient spectra for the two seagrass samples were near identical. The $\delta^{15} \mathrm{~N}$ $\beta$-coefficient plot for $Z$. muelleri leaf wrack shows peaks and troughs at 68, 76, 105, 174 and $177 \mathrm{ppm}$ (Figure S5).

\section{Discussion}

OM composition changes during decomposition

In this study, we observed statistically significant temporal shifts in the carbon composition of each of the four coastal wetland plant tissues assessed, thereby confirming our first hypothesis. The timing and nature of these shifts, however, were variable amongst the tissue types assessed (Figs. 2 and 3; Table S1), precluding a simple, universal model of 

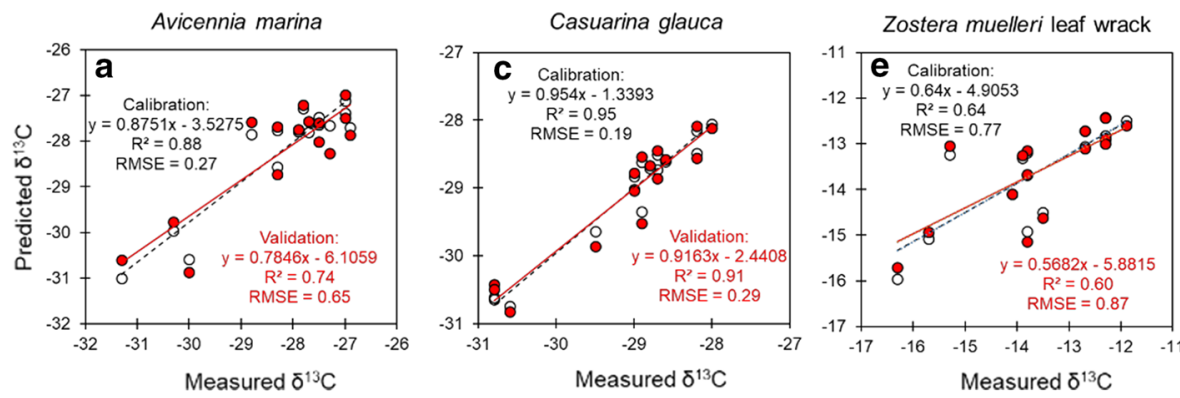

Zostera muelleri root/rhizome
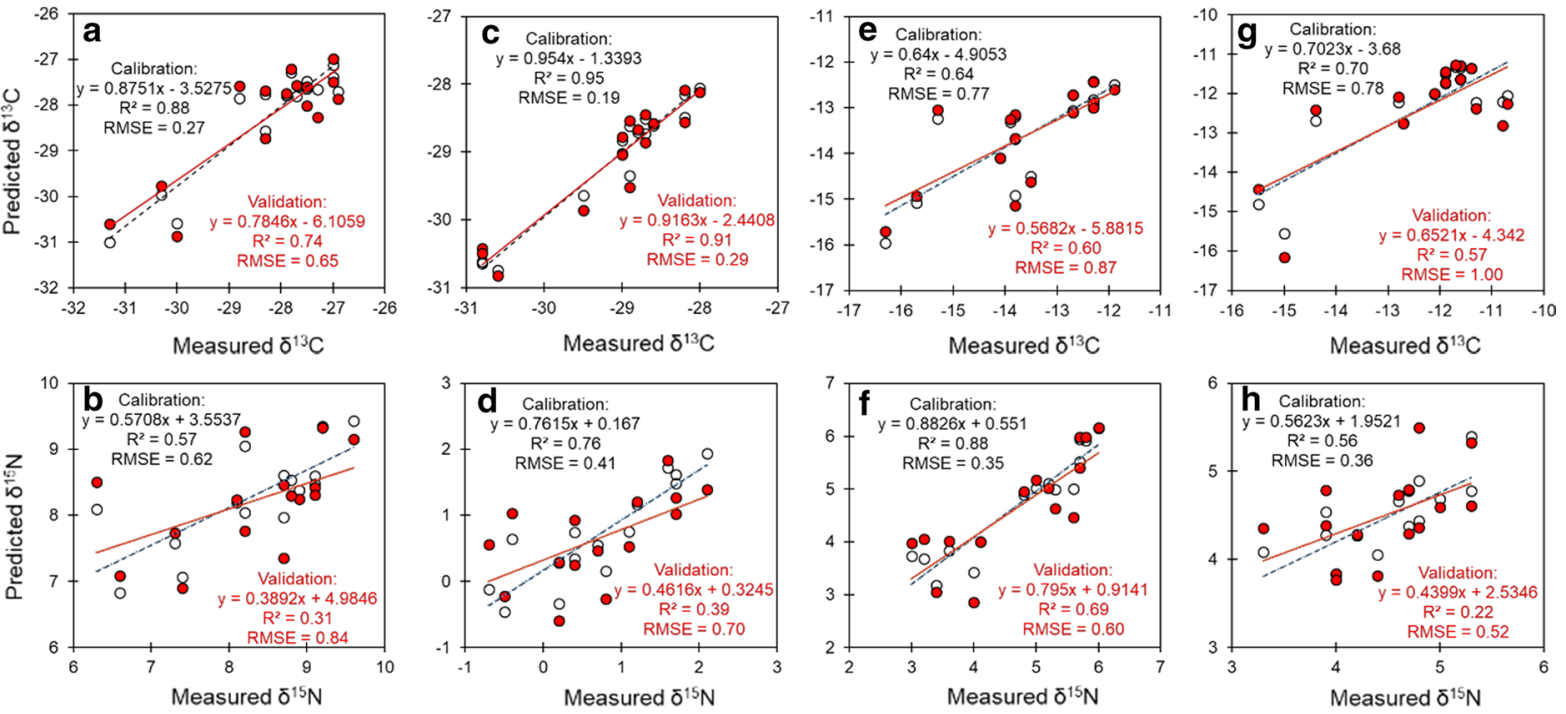

Fig. 6 Measured vs predicted plots of stable isotope ratios $\left(\delta^{13} \mathrm{C}\right.$ in top panel, $\delta^{15} \mathrm{~N}$ in lower panel) measured with isotope-ratio mass spectrometry against model-predicted values from partial least square regression analyses of ${ }^{13} \mathrm{C} N M R$ spectra. For each measured sample there is a pair of predicted data-hollow symbols and dashed lines represent calibration

litter decomposition. For the leaves of the mangrove and branchlets of the swamp oak, compositional shifts were evident early in the sampling period (by $t_{7}$ for and $t_{21}$, respectively), consistent with the depletion of O-alkyl carbon (namely cellulose at 72-76 ppm), and shifts in O-aryl carbon (142-147 and 150-155 ppm). For these species, early diagenesis was followed by further depletion of O-alkyl and di-O-alkyl carbon (95-110 ppm), consistent with depletion of carbohydrates (Baldock \& Smernik 2002) and a corresponding relative enrichment in lignin (enrichment at $142-147 \mathrm{ppm}$ and $56 \mathrm{ppm}$, albeit with potential lignin depletion at 150-155 ppm) through the remainder of deployment. In contrast, for the seagrass Zostera muelleri, there were no consistent differences between $t_{0}$ and the first sampling period $\left(t_{14}\right)$. There were longer-term shifts for $Z$. muelleri, however, including depletions diagnostic of carbohydrates (e.g. cellulose at 72-76 ppm and $105 \mathrm{ppm}$ ), and enrichments across ranges indicative of lignin, protein and/or lipid carbon (20-60 ppm and 120-160 ppm). While our experimental methods do not preclude the incorporation of 'new' OM from microbial autotrophs or heterotrophs, these broad compositional

predictions; filled red samples and solid lines represent leaveone-out validation predictions. Linear relationships are provided by sample type: Avicennia marina leaf (a, b), Casuarina glauca branchlet (c, d), Zostera muelleri leaf wrack (e, f) and Zostera muelleri root/rhizome $(\mathbf{g}, \mathbf{h})$

shifts of carbohydrate loss and relative enrichment of lignin (and/or other components) are consistent with a body of research on plant litter decomposition. This includes mangrove and seagrass detritus studies that have recorded mineralisation of polysaccharides at 2 to 10 times greater than lignin components (Benner et al. 1990, 1984; Trevathan-Tackett et al. 2017). We therefore conclude that the compositional shifts observed are largely related to decomposition of the original vascular plant tissues.

Some of the variation between tissue types is likely explained by the different experimental conditions used in the two decomposition experiments. First, the seagrass sampling regime captured a longer period, encompassing post-leaching remineralisation and stable phases (Trevathan-Tackett et al. 2020) not captured in the shorter experiment (Critchley et al. 2021), though these do not explain the early-phase differences. The timescales under which we observe $\mathrm{OM}$ degradation influences the factors exerting control over OM turnover (Burdige 2007; Trevathan-Tackett et al. 2020). For example, decomposition studies in $\mathrm{BC}$ ecosystem typically capture the early stages of $\mathrm{OM}$ diagenesis (i.e. within the first $1-2$ years or 
less). During this time, leaching is followed by the early stages of enzymatic breakdown of the detritus by resident microbial populations. Long-term turnover of detritus ( $>5$ years) is difficult to capture within decomposition studies, yet we know this detrital OM sequestration occurs, as evidenced through biomarker studies, such as stable isotopes (Kennedy et al. 2010).

The varied inundation conditions for seagrass (subtidal settings for leaf wrack, and within the rhizosphere for root/rhizome) compared to A. marina and C. glauca (exposed to sub-daily wetting and drying cycles on the wetland surface in the mid intertidal zone) were likely important. Less oxic conditions in the seagrass deployment would explain slower decomposition (Wang et al. 2019). A lack of significant differences in composition of $t_{0}$ versus all collections other than $\mathrm{t}_{729}$ for $Z$. muelleri leaves, might also be explained by our use of leaf wrack from $t_{0}$ which would have undergone some early leaching and/ or diagenesis prior to collection (Trevathan-Tackett et al. 2020), thereby missing potentially significant early changes in macromolecular content and/or isotopic signatures. The presence of microbe-associated OM (either autotrophs or heterotrophs) on this wrack material also cannot be discounted.

There were, however, several differences in decomposition amongst tissues subjected to identical deployment regimes. For example, the ${ }^{13} \mathrm{C}$ NMR spectra for A. marina differed from C. glauca in two key ways. First, the A. marina spectra showed an enrichment in alkyl carbon (20-40 ppm) (Fig. 2a), which was important to the separation of samples collected early $\left(t_{0}\right.$ and $\left.t_{7}\right)$ versus later ( $t_{21}$ onwards) in the experiment (Figure S1a, c). In contrast, $C$. glauca exhibited a depletion in this region (Fig. 2b; Figure $\mathrm{S} 1 \mathrm{~b}, \mathrm{~d})$. The second difference between these species was the initial and rapid depletion at $56 \mathrm{ppm}$ (methoxy C) for A. marina, versus a later enrichment here for $C$. glauca. These differences might be attributed to a higher proportion of lignin (methoxy C) loss from mangrove leaves, but long-term preservation of mangrove leaf waxes (alkyl C) (Koch et al. 2011), relative to the highly-reduced leaf and more woody structure of $C$. glauca branchlets. These among-taxa differences highlight the significant role of the original material's chemistry in driving decomposition dynamics (Trevathan-Tackett et al. 2017), and the importance of taxon-specific assessment in understanding plant tissue diagenesis.

\section{Shifts in $\delta^{13} C$ and $\delta^{15} N$ during decomposition}

The $\delta^{13} \mathrm{C}$ and $\delta^{15} \mathrm{~N}$ values we report for $\mathrm{t}_{0}$ samples are within the range previously reported for fresh materials (or recent seagrass wrack) of these species in the study regions (Kelleway et al. 2018, 2017b; Trevathan-Tackett et al. 2020). During the decomposition phase, however, we observed large shifts in mean $\delta^{13} \mathrm{C}$ values of up to $3.1 \%$ enrichment $(A$. marina leaf) to $4.0 \%$ depletion (Z. muelleri root/ rhizome) (Table 1). These maximum $\delta^{13} \mathrm{C}$ shifts are larger than most previous reports for blue carbon ecosystems (Table 1) and larger than most estimates in the terrestrial literature (Fernandez et al. 2003; Osono et al. 2008; Schweizer et al. 1999). As with ${ }^{13} \mathrm{C}$ NMR spectra, there was division in the response of isotopic signatures between the two tree species deployments compared to the two seagrass tissue deployments. Most importantly, our comparison revealed a significant enrichment during in $\delta^{13} \mathrm{C}$ during decomposition for both tree species, contrasted by significant depletions in $\delta^{13} \mathrm{C}$ for both seagrass tissues. While we partially accept our hypothesis that there would be significant shifts in isotope signatures over time, our findings for $\delta^{13} \mathrm{C}$, and the temporally variable nature of $\delta^{15} \mathrm{~N}$ signatures, highlights a more complex circumstance.

The opposing direction of change between $A$. marina / C. glauca $\left(\delta^{13} \mathrm{C}\right.$ enrichment) and the seagrass tissues $\left(\delta^{13} \mathrm{C}\right.$ depletion) is an important outcome of this study, which we explore in the context of chemical composition changes in the following section. Regardless of direction, the magnitude of the shifts have important implications for the design and interpretation of stable isotope studies. Given that many food web and organic matter burial studies interpret shifts of $1 \%$ or less as indicative of retention of an original source material, the variations we observed during decomposition-rapid in some cases (Figure S3)-suggest quantification of diagenesis effects and/or use of appropriate litter end-members may be necessary (Dai et al. 2009). The exponential decay models for A. marina and $C$. glauca (Fig. 4a,b) and the approximately linear relationship for Z. muelleri roots/rhizomes (Fig. 4d) of the stable isotope signatures over time provide a starting point for improved estimates of these litter contributions to food webs, organic matter burial, among other applications. Further work, however, is required 
Table 1 Summary of maximum shifts and experimental conditions of mean stable isotope values relative to starting material $\left(\mathrm{t}_{0}\right)$

\begin{tabular}{|c|c|c|c|c|c|c|}
\hline \multirow[t]{2}{*}{ Species } & \multirow[t]{2}{*}{ Tissue } & \multirow[t]{2}{*}{$\begin{array}{l}\text { Deployment } \\
\text { duration }(d)\end{array}$} & \multirow[t]{2}{*}{ Experiment setting } & \multicolumn{2}{|c|}{$\begin{array}{l}\text { Shift }(\% o) \text { rela- } \\
\text { tive to } t_{0}\end{array}$} & \multirow[t]{2}{*}{ References } \\
\hline & & & & $\delta^{13} \mathrm{C}$ & $\delta^{15} \mathrm{~N}$ & \\
\hline \multicolumn{7}{|l|}{ Mangrove } \\
\hline Avicennia marina & Leaf & 77 & Field & 3.1 & 2.2 & This study* \\
\hline Avicennia marina & Leaf, green & 168 & Field & & 2.4 & Yang et al. (2018) \\
\hline Avicennia alba & Leaf, yellow & 92 & Field & -0.2 & -0.7 & Nordhaus et al. (2017) \\
\hline $\begin{array}{l}\text { Aegiceras } \\
\text { corniculatum }\end{array}$ & Leaf, yellow & 92 & Field & -0.8 & -0.4 & Nordhaus et al. (2017) \\
\hline Ceriops decandra & Leaf, yellow & 92 & Field & 0.1 & -2.1 & Nordhaus et al. (2017) \\
\hline $\begin{array}{l}\text { Sonneratia } \\
\text { caseolaris }\end{array}$ & Leaf, yellow & 92 & Field & 0.6 & -0.3 & Nordhaus et al. (2017) \\
\hline Rhizopora apiculata & Leaf, yellow & 92 & Field & -1.3 & -0.5 & Nordhaus et al. (2017) \\
\hline Rhizophora mangle & Leaf, yellow & 348 & Field & 2.0 & -2.0 & Fourqurean and Schrlau (2003) \\
\hline Bruguiera gymnorrhiza & Leaf, green & 168 & Field & & -1.4 & Yang et al. (2018) \\
\hline \multicolumn{7}{|l|}{ Seagrass } \\
\hline Zostera muelleri & Leaf wrack & 729 & Field & n.s & -2.0 & This study* \\
\hline Zostera mиelleri & Root/rhizome & 729 & Field & -4.0 & $\mathrm{n} . \mathrm{s}$ & This study* \\
\hline Halodule wrightii & Leaf & 28 & Laboratory & -0.3 & 0.4 & Macko et al. (1994) \\
\hline Thalassia testudinum & Leaf, green & 77 & Field & & 1.0 & Delgado et al. (2017) \\
\hline Thalassia testudinum & Rhizome & 77 & Field & & 0.0 & Delgado et al. (2017) \\
\hline Thalassia testudinum & Leaf, green & 348 & Field & -2.0 & $>2$ & Fourqurean and Schrlau (2003) \\
\hline Thalassia testudinum & Rhizome & 348 & Field & 0.0 & 0.0 & Fourqurean and Schrlau (2003) \\
\hline \multicolumn{7}{|l|}{ Saltmarsh } \\
\hline Spartina alterniflora & Root/rhizome & 550 & Field & 1.0 & 2.0 & Benner et al. (1991) \\
\hline Spartina alterniflora & Leaf & 60 & Laboratory & 1.99 & 3.54 & Dai (2005) \\
\hline Spartina densiflora & Leaf, green & 63 & Field & -1.2 & 1 & Lanari et al. (2018) \\
\hline Scirpus maritimus & Leaf, green & 63 & Field & -0.3 & -0.6 & Lanari et al. (2018) \\
\hline \multicolumn{7}{|l|}{ Supratidal forest } \\
\hline Casuarina glauca & Branchlet & 77 & Field & 2.4 & -2.0 & This study* \\
\hline
\end{tabular}

*Values from this study are the maximum shift in mean value from $\mathrm{t}_{0}$ observed throughout the deployment period. No values are presented (n.s.) where no significant shifts were identified (alpha level $\mathrm{P}<0.05$ ) from $\mathrm{t}_{0}$ value during the experimental period

to determine the nature of these relationships over longer timeframes (especially for A. marina and $C$. glauca), and under varied decomposition settings.

Despite significant $\delta^{15} \mathrm{~N}$ differences among sampling periods for three out of four tissues types (Tables S2 \& S3), there were few clear temporal patterns in $\delta^{15} \mathrm{~N}$ throughout the litter deployments. While a moderate relationship $\left(\mathrm{R}^{2}=0.6\right)$ was fitted for $Z$. muelleri leaf wrack, we advise against use of this as an isotope decay factor, given the potential for non-linearity here, as well as the variability in $\delta^{15} \mathrm{~N}$ across all sample types. One potential explanation for variability of $\delta^{15} \mathrm{~N}$, could be temporal variability in nitrogen loads, which vary in relation to catchment inputs (Birch et al. 2010; Oeurng et al. 2010). Benthic sediment organic matter-such as live estuarine plants-has been shown to hold $\delta^{15} \mathrm{~N}$ signatures reflective of anthropogenic nitrogen loads in the local water column (Mazumder et al. 2015), This, however, does not explain the differential shifts in $\delta^{15} \mathrm{~N}$ by $A$. marina litter (enrichment of up to $2.2 \%$ ) versus $C$. glauca (depletion of up to $2.0 \%$ ) in otherwise identical, adjacent experimental plots. Variation of $\delta^{15} \mathrm{~N}$ signatures during the decomposition process may also be influenced by the source and process of external $\mathrm{N}$ uptake from the environment by the detritus-associated microbiota to assist in the breakdown process (N immobilisation; Benner et al. 1991; Bouillon et al. 
2008; Fourqurean \& Schrlau 2003). These differences point to the importance of the original plant material, and the potential for differential responses of microbial breakdown and $\mathrm{N}$ immobilisation during the decay process among different plant substrates (Table 1), which otherwise inhabit similar physiological niches. For $\delta^{15} \mathrm{~N}$, these taxon-specific variations, combined with temporal variations, highlight the need for understanding drivers of $\delta^{15} \mathrm{~N}$ variation in coastal wetland litters before this parameter can be reliably used in source attribution studies.

Relationships between organic matter composition and stable isotope signatures

In this study, we've been able to quantify relationships between bulk sample composition and selected stable isotope signatures. Generally, we found much stronger relationships between ${ }^{13} \mathrm{C}$ NMR spectra and $\delta^{13} \mathrm{C}$, rather than with $\delta^{15} \mathrm{~N}$. This is not particularly surprising, given that our composition method specifically assesses carbon rather than nitrogen atoms, though ${ }^{13} \mathrm{C}$ NMR is useful for the inference of noncarbon organic matter, especially via carbon associated with plant amide, nitrile and nitro compounds.

Much of the literature on isotopic signature changes during plant material decomposition is framed around differences in the $\delta^{13} \mathrm{C}$ signatures of cellulose and lignin. Various studies report cellulose as more enriched in ${ }^{13} \mathrm{C}$ than lignin (Fernandez et al. 2003; Loader et al. 2003); more depleted than lignin (Gori et al. 2013); or opposing $\delta^{13} \mathrm{C}$ trends during lignin accumulation among $\mathrm{C} 3$ and $\mathrm{C} 4$ plants (Wedin et al. 1995). While our interpretation of ${ }^{13} \mathrm{C}$ NMR spectra emphasises a loss of carbohydrate carbon during decomposition, and a relative accumulation of lignin and other resistant molecules (see section above), the influence of these changes on samples $\delta^{13} \mathrm{C}$ is inconsistent among samples (see lower panels of Figs. 2 and 3).

First, we see the loss of O-alkyl carbon (65-85 ppm; diagnostic of carbohydrates including cellulose) being strongly associated an enrichment in $\delta^{13} \mathrm{C}$ (signified by a negative coefficient operating on a negative $\delta$ value) for A. marina and C. glauca, versus a net depletion effect in the $Z$. muelleri tissues. An opposing contrast is seen in disparate depletion effect (C. glauca, A. marina) versus enrichment effect (Z. meulleri) centred at $105 \mathrm{ppm}$-which is also diagnostic of cellulose. Second, inspection of the $\beta$-coefficients for $C$. glauca (the species for which lignin accumulation was most apparant) shows a similarly complex circumstance for lignin. That is, while $\beta$-coefficients peaks at 150-155 (O-aryl carbon) and $56 \mathrm{ppm}$ (methoxy carbon) suggest the accumulation of some lignin components results in an enriched $\delta^{13} \mathrm{C}$ prediction, the loss of carbon in the 142-147 ppm range (also diagnostic of lignin) did not appear influential to $\delta^{13} \mathrm{C}$. Together, these outcomes suggest that although $\delta^{13} \mathrm{C}$ are associated with species-specific changes in lignin and cellulose contents and composition, these shifts are complex, and potentially divergent among taxa of diverse initial $\delta^{13} \mathrm{C}$ signatures.

There are multiple biochemical processes that may contribute to concurrent and related shifts we observed in litter composition and $\delta^{13} \mathrm{C}$ signature of each tissue type. In addition to the changes in the original plant material during decomposition, there is also the potential for (1) isotopic fractionation resulting from microbial processing of the plant material; and/or (2) the introduction of 'new' carbon through autotrophic fixation during litterbag deployment. Our approach of rinsing detritus prior to analysis, combined with the characteristic decomposition patterns of vascular plants described earlier, suggest the latter is unlikely. Nevertheless, teasing apart the importance of these different processes is difficult. For instance, the increased contribution of alkyl carbon (0-45 ppm) over time in A. marina and both Z. muelleri tissues may be due to the concentration of plant aliphatic carbon (such as the accumulation of leaf waxes we propose above), but may also be due to incorporation of new biomass rich in alkyl C-such as microalgae and/ or bacterial biomass (Yao et al. 2019). Such a contribution from algal and/or bacterial sources might also explain the contrasting directional $\delta^{13} \mathrm{C}$ shifts in our study. Compound-specific isotope analyses of temperate Australian mudflats have revealed bacterial and algal fatty acids signatures across a range of $\delta^{13} \mathrm{C}$ values $(-12.3$ to $-26.4 \%$ ), with most sitting between the bulk values we recorded for fresh or decomposed C3 trees and seagrass tissues (Cook et al. 2004). Further evidence for a contribution of heterotrophic biomass to isotope shifts might be seen in the moderate-strong predictive capacity observed for $\delta^{15} \mathrm{~N}$ was $Z$. muelleri leaf wrack $\left(\mathrm{R}^{2}=0.69\right.$; prediction $\mathrm{RMSE}=0.6 \%$ ), which was also the only tissue to show a discernible 
shift in $\delta^{15} \mathrm{~N}$ signature over the course of deployment (Fig. 5). Significant peaks and troughs in the $\delta^{15} \mathrm{~N}$ $\beta$-coefficient plot at 68, 76, 105, 174 and $177 \mathrm{ppm}$ (Figure S5) suggest a mix of protein plus non-plant (e.g. chitin) and/or plant carbohydrates may be driving the $\delta^{15} \mathrm{~N}$ shift.

Even though our PLS regression analyses showed that some tissue isotope values can be reliably predicted on the basis of sample composition, the numerous inter- and intra-species complexities we have discussed here preclude a simple explanation of isotopic signature shifts on the basis of plant-material molecular shifts alone. Instead, a combination of compositional shifts in original plant material, isotopic fractionations induced by microbial processing and/or incorporation of new algal or bacterial biomass likely drive changes in isotope signatures during in situ decomposition.

Implications for stable isotope research

1. Significant shifts in both the molecular composition and stable isotope signatures of each of our four study tissues emphasise the need for consideration and accounting of decomposition effects in sourceattribution studies. While the selection of end-members will vary with each study's specific objectives, our findings show that decomposition stage (e.g. live tissue vs litter collected at a specific position along the decay continuum) is a crucial factor in coastal wetland studies. In some circumstances it might be appropriate to apply post-hoc fractionation correction factors (e.g. using relationships like those presented in Fig. 4), though this will depend upon data availability for a given species and/or setting, and the nature and strength of any relationships.

2. An increasingly common use of $\delta^{13} \mathrm{C}$ and/or $\delta^{15} \mathrm{~N}$ in coastal wetland studies is to demonstrate and/ or quantify the stability of carbon down sediment cores (e.g. Adame et al. 2019). Based on the strength of some of our predictive models (Fig. 6), we argue it might be possible to utilise $\delta^{13} \mathrm{C}$ and/or $\delta^{15} \mathrm{~N}$ as a quantitative indicator of decomposition status, though capacity will vary among species and isotopes. To achieve this, however, further investigation of the relationships between decomposition and isotopic fractionation are required for a more diverse range of species. Investigation is specifically required for belowground tissues, which (i) are poorly represented in fractionation studies; (ii) make significant contributions to long-term blue carbon storage (Donato et al. 2011; Lamont et al. 2019); and (iii) may differ in response to aboveground tissues of the same species (see comparisons of leaf and root/rhizome for $Z$. muelleri in this study). Further quantification of early versus late stage decomposition effects is also needed to bridge the temporal gap between most decomposition studies (days to a few years) and blue carbon sequestration (decades to millennia).

3. Most studies which incorporate stable isotope approaches assess the isotopic signatures of their target organisms and/or end-members using bulk samples. The bulk sample approach in this study is therefore the appropriate scale for initial investigations as it integrates decomposition and isotope dynamics over a broad molecular range (i.e. all of the major $\mathrm{C}$ functional groups in a tissue). As we describe above, however, there are challenges in determining the relative importance of specific molecules (if any) to isotopic shifts using this bulk approach. In many cases, compound-specific stable isotope analysis and other emerging techniques may be needed to isolate and quantify the specific molecular drivers of isotope fractionation (Geraldi et al. 2019; Larsen et al. 2013). New insights will emerge from the complimentary use of both bulk sample and compound-specific approaches.

4. We cannot discount the possibility that the disparate deployment conditions and duration influenced the disparate outcomes we observed among the tree species and seagrass. While there were sufficient contrasts within each experimental setup to suggest nonexperimental artefacts, the deployment of all tissue types under identical conditions would help to confirm some of the biochemical processes we propose above. There is also a need for controlled experiments to quantify the importance of any microbial fractionation effects and/or new, in-situ autotrophic fixation on litterbag experiments and stable isotope signatures.

\section{Conclusions}

Our approach of analysing fresh plant materials and successive bulk litter samples via both stable isotope mass spectrometry and ${ }^{13} \mathrm{C}$ NMR spectroscopy provided an opportunity to understand the nature of compositional changes during in-situ plant material 
diagenesis and its relationship with bulk stable isotope signatures in coastal wetlands. Across all tissues assessed, we observed statistically significant shifts in sample composition across the course of deployment. These shifts can be largely explained by the preferential loss of more labile constituents and concentration of more resistant macromolecules, such as lignin and leaf waxes, though the potential for incorporation of new microbial biomass cannot be discounted.

At the same time, we recorded significant variations in sample $\delta^{13} \mathrm{C}$ over the course of deployment for all tissues assessed, and in sample $\delta^{15} \mathrm{~N}$ for three of the four tissues. While $\delta^{15} \mathrm{~N}$ variations showed few, if any, clear temporal trends, we observed exponential decays in $\delta^{13} \mathrm{C}$ for $C$. glauca and A. marina, and approximately linear decays for the seagrass tissues. Importantly, these $\delta^{13} \mathrm{C}$ shifts were in opposite directions for the two tree species (enrichment in $\delta^{13} \mathrm{C}$ over time) compared to the seagrass (depletion in $\delta^{13} \mathrm{C}$ over time).

The capacity to predict sample stable isotope values from ${ }^{13} \mathrm{C}$ NMR spectra varied among plant taxa, and among the two isotopes tested. While predictive capacity for $\delta^{13} \mathrm{C}$ was high for $C$. glauca and $A$. marina and moderate for seagrass, inspection of regression $\beta$-coefficients highlighted inter- and intraspecies complexities, which preclude a simple explanation of isotopic signature shifts based on plant molecular shifts alone. Instead, we hypothesise that a combination of compositional shifts in original plant material, isotopic fractionations induced by microbial processing and/or incorporation of new algal or bacterial biomass likely drive changes in isotope signatures during in situ decomposition.

Our findings add to a growing body of literature advocating caution in the use and interpretation of stable isotopes as bioindicators of blue carbon providence. We emphasise the need for: (1) accounting of diagenesis effects, and/or using appropriately decomposed litter end-members when attempting source-tracing; and (2) controlled decomposition studies and/or compound-specific analyses to better understand the relationships of between sample composition and isotopic signatures across a range of coastal plant taxa and decomposition settings.

Acknowledgements We acknowledge the Darug and Darkinjung traditional owners of the estuaries where this research was conducted. Janine McGowan and Bruce Hawke assisted with sample preparation and spectroscopic methods.

Author contributions JK conceived the study, undertook data analysis and prepared all figures. JB also undertook data analysis. STT and LC conceived the original litterbag experiments and undertook sample collection. All authors contributed to the generation of data and the writing and reviewing of the manuscript.

Funding Open Access funding enabled and organized by CAUL and its Member Institutions. Original sample collection was supported by a PADI Foundation Grant and analysis supported by the CSIRO Coastal Carbon Cluster. JK was supported by Macquarie University's MQRF and University of Wollongong's Vice-Chancellor's Research Fellowship. STT was supported by Deakin University's ADPRF and the ARC DE210101029.

Data availability The datasets generated during and/or analysed during the current study are available in the supplementary material.

Code availability Not applicable.

\section{Declarations}

Conflict of interest All Authors declare that they have no competing interest.

Open Access This article is licensed under a Creative Commons Attribution 4.0 International License, which permits use, sharing, adaptation, distribution and reproduction in any medium or format, as long as you give appropriate credit to the original author(s) and the source, provide a link to the Creative Commons licence, and indicate if changes were made. The images or other third party material in this article are included in the article's Creative Commons licence, unless indicated otherwise in a credit line to the material. If material is not included in the article's Creative Commons licence and your intended use is not permitted by statutory regulation or exceeds the permitted use, you will need to obtain permission directly from the copyright holder. To view a copy of this licence, visit http://creativecommons.org/licenses/by/4.0/.

\section{References}

Abrantes KG, Johnston R, Connolly RM, Sheaves M (2015) Importance of mangrove carbon for aquatic food webs in wet-dry tropical estuaries. Estuaries Coasts 38(1):383-399

Adame MF, Reef R, Wong VNL, Balcombe SR, Turschwell MP, Kavehei E, Rodríguez DC, Kelleway JJ, Masque P, Ronan M (2019) Carbon and nitrogen sequestration of melaleuca floodplain wetlands in tropical Australia. Ecosystems 23(2):454-466

Alongi DM (2014) Carbon cycling and storage in mangrove forests. Ann Rev Mar Sci 6:195-219 
Alongi DM, Boto KG, Tirendi F (1989) Effect of exported mangrove litter on bacterial productivity and dissolved organic carbon fluxes in adjacent tropical nearshore sediments. Marine Ecol Progr Ser Oldendorf 56(1):133-144

Arndt S, Jørgensen BB, LaRowe DE, Middelburg JJ, Pancost RD, Regnier P (2013) Quantifying the degradation of organic matter in marine sediments: a review and synthesis. Earth Sci Rev 123:53-86

Baldock JA, Smernik RJ (2002) Chemical composition and bioavailability of thermally altered Pinus resinosa (Red pine) wood. Org Geochem 33(9):1093-1109

Baldock JA, Masiello C, Gelinas Y, Hedges J (2004) Cycling and composition of organic matter in terrestrial and marine ecosystems. Mar Chem 92(1):39-64

Baldock JA, Hawke B, Sanderman J, Macdonald LM (2013a) Predicting contents of carbon and its component fractions in Australian soils from diffuse reflectance midinfrared spectra. Soil Research 51(8):577

Baldock JA, Sanderman J, Macdonald LM, Puccini A, Hawke B, Szarvas S, McGowan J (2013b) Quantifying the allocation of soil organic carbon to biologically significant fractions. Soil Res 51(8):561-576

Ball MC (1988) Ecophysiology of mangroves. Trees 2(3):129-142

Beer S (1989) Photosynthesis and photorespiration of marine angiosperms. Aquat Bot 34(1-3):153-166

Benner R, Newell S, Maccubbin A, Hodson RE (1984) Relative contributions of bacteria and fungi to rates of degradation of lignocellulosic detritus in salt-marsh sediments. Appl Environ Microbiol 48(1):36-40

Benner R, Fogel ML, Sprague EK, Hodson RE (1987) Depletion of $13 \mathrm{C}$ in lignin and its implications for stable carbon isotope studies. Nature 329(6141):708-710

Benner R, Hatcher PG, Hedges JI (1990) Early diagenesis of mangrove leaves in a tropical estuary: bulk chemical characterization using solid-state 13C NMR and elemental analyses. Geochim Cosmochim Acta 54(7):2003-2013

Benner R, Fogel ML, Sprague EK (1991) Diagenesis of belowground biomass of Spartina alterniflora in saltmarsh sediments. Limnol Oceanogr 36:1358-1374

Birch GF, Cruickshank B, Davis B (2010) Modelling nutrient loads to Sydney estuary (Australia). Environ Monit Assess 167(1-4):333-348

Boecklen WJ, Yarnes CT, Cook BA, James AC (2011) On the use of stable isotopes in trophic ecology. Annu Rev Ecol Evol Syst 42:411-440

Bouillon S, Connolly RM, Lee SY (2008) Organic matter exchange and cycling in mangrove ecosystems: recent insights from stable isotope studies. J Sea Res 59(1-2):44-58

Bouillon S, Connolly R, Gillikin D (2011) Use of stable isotopes to understand food webs and ecosystem functioning in estuaries. In: Wolanski E, McLusky DS (eds) Treatise on Estuarine and Coastal Science. Academic Press, Waltham, pp 143-173

Burdige DJ (2007) Preservation of organic matter in marine sediments: controls, mechanisms, and an imbalance in sediment organic carbon budgets? Chem Rev 107(2):467-485
Cebrián J, Duarte CM, Marbà N, Enríquez S (1997) Magnitude and fate of the production of four co-occurring Western Mediterranean seagrass species. Mar Ecol Prog Ser 155:29-44

Cernusak LA, Ubierna N, Winter K, Holtum JA, Marshall JD, Farquhar GD (2013) Environmental and physiological determinants of carbon isotope discrimination in terrestrial plants. New Phytol 200(4):950-965

Cole ML, Valiela I, Kroeger KD, Tomasky GL, Cebrian J, Wigand C, McKinney RA, Grady SP, Carvalho da Silva MH (2004) Assessment of a $\delta 15 \mathrm{~N}$ isotopic method to indicate anthropogenic eutrophication in aquatic ecosystems. J Environ Qual 33(1):124-132

Cook P, Revill A, Clementson L, Volkman J (2004) Carbon and nitrogen cycling on intertidal mudflats of a temperate Australian estuary. III. Sources of organic matter. Mar Ecol Prog Ser 280:55-72

Cragg SM, Friess DA, Gillis LG, Trevathan-Tackett SM, Terrett OM, Watts JEM, Distel DL, Dupree P (2020) Vascular plants are globally significant contributors to marine carbon fluxes and sinks. Annu Rev Marine Sci 12(1): null

Critchley LP, Bugnot AB, Dafforn KA, Marzinelli EM, Bishop MJ (2021) Comparison of wrack dynamics between mangrove forests with and without seawalls. Sci Total Environ 751:141371

Cummins KW, Spengler GL, Ward GM, Speaker RM, Ovink RW, Mahan DC, Mattingly RL (1980) Processing of confined and naturally entrained leaf litter in a woodland stream ecosystem 1. Limnol Oceanogr 25(5):952-957

Dai J (2005) Changes in chemical and isotopic signatures of plant materials during degradation: implication for assessing various organic inputs in estuarine systems. Geophys Res Lett 32(13):L13608. https://doi.org/10. 1029/2005GL023133

Dai J, Sun M-Y, Culp RA, Noakes JE (2009) A laboratory study on biochemical degradation and microbial utilization of organic matter comprising a marine diatom, land grass, and salt marsh plant in estuarine ecosystems. Aquat Ecol 43(4):825-841

Dehairs F, Rao RG, Chandra Mohan P, Raman AV, Marguillier S, Hellings L (2000) Hydrobiologia 431(2/3):225-241

Delacre M, Leys C, Mora YL, Lakens D (2019) Taking parametric assumptions seriously: arguments for the use of Welch's $<\mathrm{i}>\mathrm{F}</ \mathrm{i}>$-test instead of the classical $<\mathrm{i}>\mathrm{F}<$ / i $>$-test in one-way ANOVA. Int Rev Soc Psychol 32(1):13

Delgado M, Cintra-Buenrostro CE, Fierro-Cabo A (2017) Decomposition and nitrogen dynamics of turtle grass (Thalassia testudinum) in a subtropical estuarine system. Wetlands Ecol Manage 25(6):667-681

Dickens AF, Baldock JA, Smernik RJ, Wakeham SG, Arnarson TS, Gélinas Y, Hedges JI (2006) Solid-state ${ }^{13}$ C NMR analysis of size and density fractions of marine sediments: Insight into organic carbon sources and preservation mechanisms. Geochim Cosmochim Acta 70(3):666-686

Diefendorf AF, Mueller KE, Wing SL, Koch PL, Freeman KH (2010) Global patterns in leaf ${ }^{13} \mathrm{C}$ discrimination and implications for studies of past and future climate. Proc Natl Acad Sci 107(13):5738-5743 
Diouf D, Gherbi H, Prin Y, Franche C, Duhoux E, Bogusz D (1995) Hairy root nodulation of Casuarina glauca: a system for the study of symbiotic gene expression in an actinorhizal tree. MPMI-Mol Plant Microbe Interact 8(4):532-537

Dittmar T, Hertkorn N, Kattner G, Lara RJ (2006) Mangroves, a major source of dissolved organic carbon to the oceans. Global Biogeochem Cycles 20(1)

Donato DC, Kauffman JB, Murdiyarso D, Kurnianto S, Stidham M, Kanninen M (2011) Mangroves among the most carbon-rich forests in the tropics. Nat Geosci 4(5):293-297

Duarte CM, Cebrian J (1996) The fate of marine autotrophic production. Limnol Oceanogr 41(8):1758-1766

Duarte CM, Losada IJ, Hendriks IE, Mazarrasa I, Marbà N (2013) The role of coastal plant communities for climate change mitigation and adaptation. Nat Clim Chang 3(11):961-968

Farquhar G, Richards R (1984) Isotopic composition of plant carbon correlates with water-use efficiency of wheat genotypes. Funct Plant Biol 11(6):539-552

Fernandez I, Mahieu N, Cadisch G (2003) Carbon isotopic fractionation during decomposition of plant materials of different quality. Global Biogeochem Cycles 17(3)

Fourqurean JW, Schrlau JE (2003) Changes in nutrient content and stable isotope ratios of $\mathrm{C}$ and $\mathrm{N}$ during decomposition of seagrasses and mangrove leaves along a nutrient availability gradient in Florida Bay, USA. Chem Ecol 19(5):373-390

France R (1995) Carbon-13 enrichment in benthic compared to planktonic algae: foodweb implications. Mar Ecol Prog Ser 124:307-312

Geraldi NR, Ortega A, Serrano O, Macreadie PI, Lovelock CE, Krause-Jensen D, Kennedy H, Lavery PS, Pace ML, Kaal J, Duarte CM (2019) Fingerprinting blue carbon: rationale and tools to determine the source of organic carbon in marine depositional environments. Front Marine Sci

Golchin A, Oades J, Skjemstad J, Clarke P (1995) Structural and dynamic properties of soil organic-matter as reflected by ${ }^{13} \mathrm{C}$ natural-abundance, pyrolysis mass-spectrometry and solid-state ${ }^{13} \mathrm{C}$ NMR-spectroscopy in density fractions of an oxisol under forest and pasture. Soil Research. 33(1): 59-76

Gori Y, Wehrens R, Greule M, Keppler F, Ziller L, La Porta N, Camin F (2013) Carbon, hydrogen and oxygen stable isotope ratios of whole wood, cellulose and lignin methoxyl groups of Picea abies as climate proxies. Rapid Commun Mass Spectrom 27(1):265-275

Goulter P, Allaway W (1979) Litter Fall and Decompostion in a Mangrove Stand, Avicennia marina (Forsk.) Vierh., in Middle Harbour, Sydney. Marine Freshw Res 30(4):541-546

Guest MA, Connolly RM (2004) Fine-scale movement and assimilation of carbon in saltmarsh and mangrove habitat by resident animals. Aquat Ecol 38(4):599-609

Hayes MA, Jesse A, Hawke B, Baldock J, Tabet B, Lockington D, Lovelock CE (2017) Dynamics of sediment carbon stocks across intertidal wetland habitats of Moreton Bay, Australia. Global Chang Biol

Hemminga M, Slim F, Kazungu J, Ganssen G, Nieuwenhuize J, Kruyt N (1994) Carbon outwelling from a mangrove forest with adjacent seagrass beds and coral reefs (Gazi Bay, Kenya). Marine Ecol Progr Ser 291-301

Hyndes GA, Nagelkerken I, McLeod RJ, Connolly RM, Lavery PS, Vanderklift MA (2013) Mechanisms and ecological role of carbon transfer within coastal seascapes. Biol Rev Camb Philos Soc 89(1):232-254

Jennerjahn TC (2020) Relevance and magnitude of 'Blue Carbon' storage in mangrove sediments: carbon accumulation rates vs. stocks, sources vs. sinks. Estuarine. Coast Shelf Sci 107027

Johnson BJ, Moore KA, Lehmann C, Bohlen C, Brown TA (2007) Middle to late Holocene fluctuations of C3 and C4 vegetation in a Northern New England Salt Marsh, Sprague Marsh. Phippsburg Maine Organ Geochem 38(3):394-403

Kelleway JJ, Saintilan N, Macreadie PI, Baldock JA, Heijnis H, Zawadzki A, Gadd P, Jacobsen G, Ralph PJ (2017a) Geochemical analyses reveal the importance of environmental history for blue carbon sequestration. J Geophys Res Biogeosci 122(7):1789-1805

Kelleway JJ, Saintilan N, Macreadie PI, Baldock JA, Ralph PJ (2017b) Sediment and carbon deposition vary among vegetation assemblages in a coastal salt marsh. Biogeosciences 14(16):3763-3779

Kelleway JJ, Mazumder D, Baldock JA, Saintilan N (2018) Carbon isotope fractionation in the mangrove Avicennia marina has implications for food web and blue carbon research. Estuar Coast Shelf Sci 205:68-74

Kennedy H, Gacia E, Kennedy DP, Papadimitriou S, Duarte CM (2004) Organic carbon sources to SE Asian coastal sediments. Estuar Coast Shelf Sci 60(1):59-68

Kennedy H, Beggins J, Duarte CM, Fourqurean JW, Holmer M, Marbà N, Middelburg JJ (2010) Seagrass sediments as a global carbon sink: isotopic constraints. Global Biogeochem Cycles 24(4):1-8

Kim M, Brodersen KE, Szabó M, Larkum AWD, Raven JA, Ralph PJ, Pernice M (2018) Low oxygen affects photophysiology and the level of expression of two-carbon metabolism genes in the seagrass Zostera muelleri. Photosynth Res 136(2):147-160

Koch BP, Souza Filho PWM, Behling H, Cohen MCL, Kattner G, Rullkötter J, Scholz-Böttcher B, Lara RJ (2011) Triterpenols in mangrove sediments as a proxy for organic matter derived from the red mangrove (Rhizophora mangle). Org Geochem 42(1):62-73

Krauss KW, Noe GB, Duberstein JA, Conner WH, Stagg CL, Cormier N, Jones MC, Bernhardt CE, Graeme Lockaby B, From AS, Doyle TW, Day RH, Ensign SH, Pierfelice KN, Hupp CR, Chow AT, Whitbeck JL (2018) The role of the upper tidal estuary in wetland blue carbon storage and flux. Global Biogeochem Cycles

Kristensen E, Bouillon S, Dittmar T, Marchand C (2008) Organic carbon dynamics in mangrove ecosystems: a review. Aquat Bot 89(2):201-219

Kurdali F, Al-Shamma'A M (2009) Natural abundances of ${ }^{15} \mathrm{~N}$ and ${ }^{13} \mathrm{C}$ in leaves of some N2-fixing and nonN2-fixing trees and shrubs in Syria. Isot Environ Health Stud 45(3):198-207

Lamont K, Saintilan N, Kelleway JJ, Mazumder D, Zawadzki A (2019) Thirty-year repeat measures of mangrove 
above-and below-ground biomass reveals unexpectedly high carbon sequestration. Ecosystems 23(2):370-382

Lanari M, Coelho Claudino M, Miranda Garcia A, Da Silva CM (2018) Changes in the elemental $(\mathrm{C}, \mathrm{N})$ and isotopic $\left(\delta^{13} \mathrm{C}, \delta^{15} \mathrm{~N}\right)$ composition of estuarine plants during diagenesis and implications for ecological studies. J Exp Mar Biol Ecol 500:46-54

Larsen T, Ventura M, Andersen N, O'Brien DM, Piatkowski U, McCarthy MD (2013) Tracing carbon sources through aquatic and terrestrial food webs using amino acid stable isotope fingerprinting. PLoS ONE 8(9):e73441

Lee S (2000) Carbon dynamics of Deep Bay, eastern Pearl River estuary, China. II: trophic relationship based on carbon- and nitrogen-stable isotopes. Mar Ecol Prog Ser 205:1-10

Loader NJ, Robertson I, McCarroll D (2003) Comparison of stable carbon isotope ratios in the whole wood, cellulose and lignin of oak tree-rings. Palaeogeogr Palaeoclimatol Palaeoecol 196(3-4):395-407

Loneragan NR, Bunn SE, Kellaway DM (1997) Are mangroves and seagrasses sources of organic carbon for penaeid prawns in a tropical Australian estuary? A Multiple Stable-Isotope Study Marine Biol 130(2):289-300

Macko SA, Engel MH, Qian Y (1994) Early diagenesis and organic matter preservation - a molecular stable carbon isotope perspective. Chem Geol 114(3-4):365-379

Maher DT, Santos IR, Golsby-Smith L, Gleeson J, Eyre BD (2013) Groundwater-derived dissolved inorganic and organic carbon exports from a mangrove tidal creek: the missing mangrove carbon sink? Limnol Oceanogr 58(2):475-488

Maher DT, Santos IR, Schulz KG, Call M, Jacobsen GE, Sanders CJ (2017) Blue carbon oxidation revealed by radiogenic and stable isotopes in a mangrove system. Geophys Res Lett 44(10):4889-4896

Maher DT, Call M, Santos IR, Sanders CJ (2018) Beyond burial: lateral exchange is a significant atmospheric carbon sink in mangrove forests. Biol Lett 14(7)

Marquez MA, Fierro-Cabo A, Cintra-Buenrostro CE (2017) Can ecosystem functional recovery be traced to decomposition and nitrogen dynamics in estuaries of the Lower Laguna Madre, Texas? Restor Ecol 25(4):618-628

Mazumder D, Saintilan N, Williams RJ, Szymczak R (2011) Trophic importance of a temperate intertidal wetland to resident and itinerant taxa: evidence from multiple stable isotope analyses. Mar Freshw Res 62(1):11-19

Mazumder D, Saintilan N, Alderson B, Hollins S (2015) Inputs of anthropogenic nitrogen influence isotopic composition and trophic structure in SE Australian estuaries. Marine Pollut Bull

Mazumder D, Saintilan N, Yusoff FM, Kelleway JJ (2019) Equivalence of trophic structure between a tropical and temperate mangrove ecosystem in the Indo-Pacific. Marine Freshw Res

McLeod E, Chmura GL, Bouillon S, Salm R, Björk M, Duarte CM, Lovelock CE, Schlesinger WH, Silliman BR (2011) A blueprint for blue carbon: toward an improved understanding of the role of vegetated coastal habitats in sequestering $\mathrm{CO}_{2}$. Front Ecol Environ 9(10):552-560

Nagelkerken I, Blaber S, Bouillon S, Green P, Haywood M, Kirton L, Meynecke J-O, Pawlik J, Penrose H,
Sasekumar A (2008) The habitat function of mangroves for terrestrial and marine fauna: a review. Aquat Bot 89(2):155-185

Needelman BA, Emmer IM, Emmett-Mattox S, Crooks S, Megonigal JP, Myers D, Oreska MPJ, McGlathery K (2018) The science and policy of the verified carbon standard methodology for tidal wetland and seagrass restoration. Estuaries Coast 41(8):2159-2171

Nordhaus I, Salewski T, Jennerjahn TC (2017) Interspecific variations in mangrove leaf litter decomposition are related to labile nitrogenous compounds. Estuar Coast Shelf Sci 192:137-148

Odum WE, Heald EJ (1975) The detritus-based food web of an estuarine mangrove community. In: Cronin L (ed) Estuarine research: chemistry, biology, and the estuarine system. Elsevier, New York, p 265

Oeurng C, Sauvage S, Sánchez-Pérez J-M (2010) Temporal variability of nitrate transport through hydrological response during flood events within a large agricultural catchment in south-west France. Sci Total Environ 409(1):140-149

Osono T, Takeda H, Azuma J-I (2008) Carbon isotope dynamics during leaf litter decomposition with reference to lignin fractions. Ecol Res 23(1):51-55

Ouyang X, Lee SY, Connolly RM (2017) The role of root decomposition in global mangrove and saltmarsh carbon budgets. Earth Sci Rev 166:53-63

Post DM (2002) Using stable isotopes to estimate trophic position: models, methods, and assumptions. Ecology 83(3):703-718

Rodelli M, Gearing J, Gearing P, Marshall N, Sasekumar A (1984) Stable isotope ratio as a tracer of mangrove carbon in Malaysian ecosystems. Oecologia 61(3):326-333

Rogers K, Kelleway JJ, Saintilan N, Megonigal JP, Adams JB, Holmquist JR, Lu M, Schile-Beers L, Zawadzki A, Mazumder D, Woodroffe CD (2019a) Wetland carbon storage controlled by millennial-scale variation in relative sea-level rise. Nature 567(7746):91-95

Rogers K, Saintilan N, Mazumder D, Kelleway JJ (2019b) Mangrove dynamics and blue carbon sequestration. Biol Let 15(3):20180471

Schweizer M, Fear J, Cadisch GJRCIMS (1999) Isotopic (13C) fractionation during plant residue decomposition and its implications for soil organic matter studies. Rapid Commun Mass Spectrom 13(13):1284-1290

Serrano O, Kelleway JJ, Lovelock C, Lavery PS (2019) Conservation of blue carbon ecosystems for climate change mitigation and adaptation. Coastal wetlands. Elsevier, New York, pp 965-996

Sippo JZ, Maher DT, Tait DR, Holloway C, Santos IR (2016) Are mangroves drivers or buffers of coastal acidification? Insights from alkalinity and dissolved inorganic carbon export estimates across a latitudinal transect. Global Biogeochem Cycles

Smith BN, Epstein S (1971) Two categories of ${ }^{13} \mathrm{C} /{ }^{12} \mathrm{C}$ ratios for higher plants. Plant Physiol 47(3):380-384

Spivak AC, Sanderman J, Bowen JL, Canuel EA, Hopkinson CS (2019) Global-change controls on soil-carbon accumulation and loss in coastal vegetated ecosystems. Nat Geosci 12(9):685-692 
Tanner BR, Uhle ME, Mora CI, Kelley JT, Schuneman PJ, Lane CS, Allen ES (2010) Comparison of bulk and compound-specific $\delta 13 \mathrm{C}$ analyses and determination of carbon sources to salt marsh sediments using n-alkane distributions (Maine, USA). Estuar Coast Shelf Sci 86(2):283-291

Trevathan-Tackett SM, Kelleway JJ, Macreadie PI, Beardall J, Ralph P, Bellgrove A (2015) Comparison of marine macrophytes for their contributions to blue carbon sequestration. Ecology 96(11):3043-3057

Trevathan-Tackett SM, Seymour JR, Nielsen DA, Macreadie PI, Jeffries TC, Sanderman J, Baldock J, Howes JM, Steven ADL, Ralph PJ (2017) Sediment anoxia limits microbial-driven seagrass carbon remineralization under warming conditions. FEMS Microbiol Ecol 93(6)

Trevathan-Tackett SM, Jeffries TC, Macreadie PI, Manojlovic B, Ralph P (2020) Long-term decomposition captures key steps in microbial breakdown of seagrass litter. Sci Total Environ 705:135806

Wang ZA, Kroeger KD, Ganju NK, Gonneea ME, Chu SN (2016) Intertidal salt marshes as an important source of inorganic carbon to the coastal ocean. Limnol Oceanogr 61(5):1916-1931

Wang F, Kroeger KD, Gonneea ME, Pohlman JW, Tang J (2019) Water salinity and inundation control soil carbon decomposition during salt marsh restoration: an incubation experiment. Ecol Evol 9(4):1911-1921
Wedin DA, Tieszen LL, Dewey B, Pastor JJE (1995) Carbon isotope dynamics during grass decomposition and soil organic matter formation. Ecology 76(5):1383-1392

Wold S, Sjöström M, Eriksson L (2001) PLS-regression: a basic tool of chemometrics. Chemom Intell Lab Syst 58(2):109-130

Yang Z, Song W, Zhao Y, Zhou J, Wang Z, Luo Y, Li Y, Lin G (2018) Differential responses of litter decomposition to regional excessive nitrogen input and global warming between two mangrove species. Estuar Coast Shelf Sci 214:141-148

Yao S, Lyu S, An Y, Lu J, Gjermansen C, Schramm A (2019) Microalgae-bacteria symbiosis in microalgal growth and biofuel production: a review. J Appl Microbiol 126(2):359-368

Zieman J, Macko S, Mills AJBoMS (1984) Role of seagrasses and mangroves in estuarine food webs: temporal and spatial changes in stable isotope composition and amino acid content during decomposition. Bull Marine Sci 35(3):380-392

Publisher's Note Springer Nature remains neutral with regard to jurisdictional claims in published maps and institutional affiliations. 